Postgraduate Bosowa University Publishing (PBUP)
Indonesian Journal of Business and Management
e-ISSN: $2460-3767 \quad p$-ISSN: $2656-6885$
inttps://postgraduate.universitasbosowan
JOURAL

\title{
ANALISIS MOTIVASI, DISIPLIN KERJA DAN SARANA PRASARANA TERHADAP KINERJA PEGAWAI MELALUI KEPUASAN KERJA DI KANTOR BADAN KEPEGAWAIAN DAN PENGEMBANGAN SUMBER DAYA MANUSIA KABUPATEN BANTAENG PROVINSI SULAWESI SELATAN
}

\author{
Analysis of Motivation, Work Discipline and Infrastructure on Employee Performance through Job \\ Satisfaction at the Office of the Personnel and Human Resources Development Agency, Bantaeng \\ Regency, South Sulawesi Province
}

\author{
Fatwa Rezki ${ }^{1}$, Hasanuddin Remmnag ${ }^{2}$, Chahyono $^{2}$ \\ ${ }^{1}$ BKPSDM Kabupaten Bantaeng \\ ${ }^{2}$ Program Studi Manajemen Program Pascasarjana Universitas Bosowa \\ Email: fatwarezki95@gmail.com
}

Diterima: 20 September 2021/Disetujui: 24 Desember 2021

\begin{abstract}
ABSTRAK
Penelitian ini bertujuan untuk mengetahui dan menganalisis pengaruh motivasi kerja, disiplin kerja, sarana dan prasarana terhadap kepuasan dan kinerja pegawai, menganalisis pengaruh kepuasan kerja terhadap kinerja pegawai, menganalisis pengaruh motivasi kerja, disiplin kerja, sarana dan prasarana terhadap kinerja pegawai melalui kepuasan kerja. Untuk mencapai tujuan tersebut maka digunakan teknik pengumpulan data melalui penyebaran kuesioner, dengan teknik analisis data menggunakan analisis regresi berganda dan uji sobel test. Hasil penelitian menemukan bahwa motivasi kerja memberikan pengaruh yang bermakna dalam meningkatkan kepuasan kerja. Disiplin kerja dapat memberikan pengaruh yang bermakna dalam meningkatkan kepuasan kerja pegawai. Sarana dan prasarana memberikan pengaruh yang bermakna dalam meningkatkan kepuasan kerja pegawai. Kepuasan pegawai memberikan pengaruh yang bermakna dalam meningkatkan kinerja pegawai. Kepuasan kerja dapat memediasi secara parsial pengaruh motivasi kerja terhadap kinerja pegawai. Kepuasan kerja dapat memediasi secara parsial pengaruh disiplin kerja terhadap kinerja pegawai. Kepuasan kerja dapat memediasi secara parsial pengaruh sarana dan prasarana terhadap kinerja pegawai pada BKPSDM Kabupaten Bantaeng Provinsi Sulawesi Selatan.
\end{abstract}

Kata Kunci: Motivasi, Disiplin Kerja, Sarana Prasarana, Kepuasan Kerja dan Kinerja

\section{ABSTRACT}

This study aims to determine and analyze the effect of work motivation, work discipline, facilities and infrastructure on employee satisfaction and performance, analyze the effect of job satisfaction on employee performance, analyze the effect of work motivation, work discipline, facilities and infrastructure on employee performance through job satisfaction. To achieve this goal, data collection techniques were used through the distribution of questionnaires, with data analysis techniques using multiple regression analysis and Sobel test. The results of the study found that work motivation had a significant effect on increasing job satisfaction. Work discipline can have a significant effect in increasing employee job satisfaction. Facilities and infrastructure have a significant influence in increasing employee job satisfaction. Employee satisfaction has a significant effect in improving employee performance. Job satisfaction can partially mediate the effect of work motivation on employee performance. Job satisfaction can partially mediate the effect of work discipline on employee performance. Job satisfaction can partially mediate the effect of facilities and infrastructure on employee performance at BKPSDM Bantaeng Regency, South Sulawesi Province.

Keywords: Motivation, Work Discipline, Infrastructure, Job Satisfaction and Performance Employee. 


\section{PENDAHULUAN}

Era globalisasi dewasa ini penuh dengan tantangan, oleh karena itu keberadaan pegawai merupakan aspek yang terpenting bagi terwujudnya rencana organisasi yang telah ditetapkan. Peranan sumber daya manusia akan semakin penting mengingat hal tersebut, sudah menjadi sebuah keharusan bagi organisasi untuk memperhatikan pengelolaan sumber daya manusia. Karena kegagalan dalam pengelolaan sumber daya manusia dalam organisasi akan mendatangkan kerugian bagi organisasi yaitu tidak tercapainya tujuan yang telah ditetapkan begitupun sebaliknya.

Sumber daya manusia merupakan aset organisasi yang sangat vital, karena itu peran dan fungsinya tidak bisa digantikan oleh sumber daya lainnya. Betapapun modern teknologi yang digunakan, atau seberapa banyak dana yang disiapkan, namun tanpa sumber daya manusia yang profesional semuanya menjadi tidak bermakna (Yuniarsih \& Suwatno, 2018). Salah satu cara dalam menghadapi tantangan tersebut adalah dengan meningkatkan kinerja pegawainya. Kinerja pegawai akan mencerminkan kinerja organisasi. Wibowo (2016) mengatakan bahwa kinerja merupakan implementasi dari rencana yang telah disusun tersebut. Implementasi kinerja dilakukan oleh SDM yang memiliki kemampuan, kompetensi, motivasi dan kepentingan. Bagaimana organisasi menghargai dan memperlakukan sumberdaya manusianya akan mempengaruhi sikap perilakunya dalam menjalankan kinerja.

Untuk meningkatkan kinerja pegawai perlunya diperhatikan mengenai masalah kepuasan kerja, sebagaimana dikemukakan oleh Handoko (2014) bahwa kepuasan kerja (job satisfaction) adalah keadaan emosional yang menyenangkan atau tidak menyenangkan dengan mana para pegawai memandang pekerjaan mereka. Kepuasan kerja mencerminkan perasaan seseorang terhadap pekerjaannya. Apabila pegawai puas maka akan nampak dalam sikap positif pegawai terhadap pekerjaannya untuk lebih meningkatkan kinerja kerjanya. Parwanto dan Wahyudin (2011), yang memperoleh hasil bahwa kepuasan kerja memiliki pengaruh signifikan terhadap kinerja pegawai.

Untuk meningkatkan kinerja dan kepuasan kerja, maka perlunya motivasi kerja, dimana menurut Gibson dalam Warsito (2018) bahwa kinerja pegawai dipengaruhi oleh faktor motivasi. Faktor motivasi mempunyai hubungan langsung dengan kinerja pegawai. Oleh karena itu hubungan motivasi dan kinerja sangatlah strategis dikarenakan dalam pengembangan kinerja pegawai dapat dimulai dengan adanya peningkatan suatu motivasi. Apabila pegawai memiliki motivasi yang tinggi, maka suatu organisasi akan berjalan dengan baik dan berdampak pada kinerja pegawai yang baik pula. Penelitian Rizal, et al., (2015) dan Prasetyo (2015) menemukan bahwa motivasi kerja memiliki pengaruh yang positif dan signifikan terhadap kinerja pegawai. Selain itu motivasi berpengaruh terhadap kepuasan kerja, sebagaimana dikemukakan oleh Ansory, dkk (2018) bahwa motivasi adalah konsep yang menguraikan tentang kekuatan-kekuatan yang ada dalam diri setiap individu untuk memulai dan mengarahkan perilaku. Konsep ini digunakan untuk menjelaskan perbedaan-perbedaan dalam intensitas perilaku dimana perilaku yang bersemangat adalah hasil dari tingkat motivasi yang kuat. Artinya semakin baik motivasi yang diberikan kepada pegawai maka kepuasan kerja pegawai akan semakin meningkat. Penelitian Maharjan (2012) dan Shah et al. (2012) yang menyatakan bahwa motivasi berpengaruh positif terhadap kepuasan kerja.

Kemudian faktor kedua yang mempengaruhi kinerja dan kepuasan kerja adalah disiplin kerja, disiplin merupakan tindakan manajemen mendorong para anggota organisasi dalam memenuhi tuntutan berbagai ketentuan organisasi. Disiplin kerja berpengaruh terhadap kinerja pegawai, sebagaimana dikemukakan oleh Siagian (2017) bahwa pendisiplinan pegawai adalah suatu bentuk pelatihan yang berusaha memperbaiki dan membentuk pengetahuan, sikap dan perilaku pegawai sehingga para pegawai tersebut secara sukarela berusaha untuk bekerja secara kooperatif dengan para pegawai yang lain dalam rangka meningkatkan prestasi kerjanya. Semakin baik disiplin pegawai, semakin tinggi prestasi kerja yang dapat dicapainya. Tanpa disiplin pegawai yang baik, sulit bagi organisasi perusahaan mencapai hasil yang optimal (Hasibuan, 2019). Penelitian ini sejalan dengan yang dilakukan oleh Annita Jannah, dkk (2014) bahwa disiplin kerja secara parsial dan simultan memiliki pengaruh terhadap kinerja pegawai.

Selain itu disiplin berpengaruh terhadap kepuasan kerja sebagaimana penelitian Fatimah (2017) bahwa disiplin pegawai berpengaruh terhadap kepuasan kerja pegawai. Hal ini berarti, semakin tinggi tingkat kedisiplinan pegawai, maka kepuasan pegawai akan semakin meningkat. Sebaliknya, semakin rendah tingkat kedisiplinan pegawai, maka kepuasan pegawai akan semakin menurun. Begitu pula dengan Sukirman (2011) bahwa kepuasan kerja dan disiplin kerja pegawai memiliki adanya hubungan yang positif.

Selanjutnya sarana dan prasarana turut berperan dalam meningkatkan kinerja pegawai, sebagaimana diketahui bahwa sarana dan prasarana merupakan komponen penting dan utama dalam berjalannya suatu pekerjaan. Pekerjaan tidak dapat diselesaikan oleh pegawai dengan cepat dan mudah tanpa adanya bantuan dari sarana prasarana yang memadai. Oleh karena itu Bohari (2019) mengatakan bahwa jika sarana prasarana kerja tersebut baik, maka dapat mempengaruhi kinerja pegawai yang baik pula dan apabila sarana prasarana tersebut buruk, maka kinerja pegawai juga tidak akan maksimal. Oleh karena itu, adanya sarana prasarana tentu akan mempengaruhi hasil kinerja pegawai. Penelitian Syafaruddin (2013) dan Didi Hartono (2014), hasil temuan bahwa sarana prasarana memberikan pengaruh positif dan signifikan terhadap kinerja pegawai.

Kemudian sarana prasarana berpengaruh terhadap kepuasan kerja sebagaimana penelitian Rustam (2012) bahwa sarana prasarana berpengaruh positif dan signifikan terhadap 
kepuasan kerja, dimana sarana dan prasarana sangat memberi dampak yang besar terhadap keberhasilan guru dalam menyampaikan materi, selain keberhasilan dalam menyampaikan materi juga akan mengarah kepada kepuasan kerja.

Kepuasan kerja dijadikan sebagai variabel mediasi antara pengaruh motivasi terhadap kinerja melalui kepuasan kerja, hal ini sesuai teori yang dikemukakan oleh Hasibuan (2019) bahwa motivasi adalah pemberian daya penggerak yang menciptakan kegairahan kerja seseorang, agar mereka mau bekerja sama, bekerja efektif dan terintegrasi dengan segala daya upayanya untuk mencapai kepuasan. Murti dan Srimulyani (2013) yang menyatakan bahwa terdapat hubungan mediasi antara motivasi kerja terhadap kinerja pegawai melalui kepuasan kerja. Kemudian kepuasan kerja dapat memediasi pengaruh disiplin terhadap kinerja pegawai, dimana Penelitian Filliantoni, dkk. (2019) menemukan bahwa kepuasan kerja dapat memediasi pengaruh kedisiplinan terhadap kinerja pegawai. Begitu pula kepuasan kerja dapat memediasi pengaruh sarana prasarana terhadap kinerja pegawai, hal ini sesuai dengan penelitian Putro (2013) hasil temuan bahwa ada hubungan positif antara kinerja dengan sarana dan prasarana melalui kepuasan kerja pegawai.

Penelitian ini dilakukan pada Kantor Badan Kepegawaian dan Pengembangan Sumber Daya Manusia Kabupaten Bantaeng Provinsi Sulawesi Selatan, yang memiliki visi yakni mewujudkan pemerintahan yang berorientasi melayani dan inovatif, dengan tujuan meningkatkan kualitas penyelenggaraan pemerintahan dan pelayanan, serta meningkatnya akuntabilitas kinerja pemerintah. Oleh karena itu untuk mencapai visi dan misi yang telah ditetapkan oleh organisasi maka perlunya dituntut kinerja kerja yang tinggi, karena permasalahan yang terjadi selama ini bahwa kinerja pegawai belum optimal. Penyebab kinerja pegawai belum optimal karena kurangnya kepuasan kerja pegawai, hal ini dapat dilihat dari kurangnya tunjangantunjangan kinerja yang diberikan organisasi, kurangnya insentif, sarana dan prasarana serta iklim kerja yang tidak mendukung, kurangnya terjalin kerjasama yang baik dengan sesama rekan kerja, serta kurangnya peluang pengembangan karir atau promosi jabatan bagi setiap pegawai, sehingga hal ini yang mempengaruhi pencapaian kinerja kurang optimal.

\section{METODE}

\section{a. Jenis Penelitian}

Jenis penelitian adalah rencana menyeluruh dari penelitian mencakup hal-hal yang akan dilakukan peneliti dan membuat hipotesis serta implikasi secara operasional sampai tahap akhir dengan menganalisis data yang diperoleh dari kuesioner sebagai alat pengumpul data primer untuk memperoleh bukti mengenai pengaruh motivasi, disiplin kerja dan sarana prasaran terhadap kinerja pegawai melalui kepuasan kerja pegawai. Pendekatan penelitian ini menggunakan pendekatan kuantitatif. Menurut Sugiyono (2016) metode penelitian kuantitatif adalah sebagai penelitian yang berlandaskan pada sampel filsafat positivisme, digunakan untuk meneliti pada populasi atau sampel tertentu, pengumpulan data menggunkan istrumen penelitian, analisis data bersifat kuantitatif statistik, dengan tujuan untuk menguji hipotesis yang telah ditetapkan.

\section{b. Populasi dan Sampel}

Populasi diartikan sebagai wilayah generalisasi yang terdiri atas objek atau subjek yang mempunyai kualitas dan karakteristik tertentu yang diterapkan oleh peneliti untuk dipelajari dan kemudian ditarik kesimpulan, Sugiyono (2016). Adapun populasi dalam penelitian ini adalah seluruh pegawai yang bekerja di Badan Kepegawaian Pengembangan Sumberdaya Manusia Kabupaten Bantaeng yang berjumlah 56 Orang pegawai, dengan perincian 27 orang PNS dan 29 orang Non PNS. Menurut Sugiyono, (2016) sampel merupakan bagian dari jumlah dan karakteristik yang dimiliki oleh populasi tersebut. Teknik sampel yang digunakan dalam penelitian ini yaitu sampel jenuh dimana pegawai yang berjumlah sebanyak 56 dijadikan sebagai sampel dalam penelitian.

\section{c. Variabel Penelitian}

Pada penelitian ini terdapat tiga macam variabel, yaitu variabel terikat (variabel dependen) merupakan variabel yang tergantung dengan variabel yang lainnya dan variabel bebas (variabel independen) merupakan variabel yang tidak memiliki ketergantungan terhadap variabel yang lainnya. serta variabel mediasi. Variabel yang digunakan dalam penelitian ini antara lain :

1. Variabel Independen (X)

Variabel independen atau variabel bebas merupakan variabel yang mempengaruhi atau menjadi sebab perubahan atau timbulnya variabel dependen (terikat). Variabel independen dalam penelitian ini adalah Motivasi kerja (X1) dan Disiplin kerja (X2) serta sarana prasarana (X3).

2. Variabel Dependen $(\mathrm{Z})$

Variabel dependen atau variabel terikat merupakan variabel yang dipengaruhi atau yang menjadi akibat karena adanya variabel bebas. Variabel dependen dalam penelitian ini adalah kinerja pegawai $(\mathrm{Z})$

3. Variabel Mediasi (Y)

Variabel mediasi adalah variabel antara yang menghubungkan variabel independen utama pada variabel dependen yang di analisis. Variabel mediasi berperan sama dengan fungsi variabel dependen (Sekaran, 2016). Variabel mediasi pada penelitian ini adalah kepuasan $\operatorname{kerja}(\mathrm{Y})$.

\section{d. Jenis dan Sumber Data}

Adapun jenis data yang digunakan dalam penelitian ini adalah sebagai berikut :

1. Data kuantitatif, yaitu data yang diperoleh dari Badan Kepegawaian Pengem-bangan Sumberdaya Manusia Kabupaten Bantaeng dalam bentuk angkaangka yang masih perlu dianalisis kembali, seperti : jumlah pegawai, serta data lainnya yang menunjang pembahasan ini.

2. Data kualitatif, yaitu data yang diperoleh dari Badan Kepegawaian Pengembangan Sumberdaya Manusia 
Kabupaten Bantaeng dalam bentuk informasi baik secara lisan maupun tulisan, yang berperan sebagai data pendukung dalam penyusunan tesis ini, misalnya profil Badan Kepegawaian Pengembangan Sumberdaya Manusia Kabupaten Bantaeng, struktur organisasi dan uraian tugas masing-masing bagian dalam organisasi serta data lainnya yang menunjang pokok pembahasan. adalah:

Sumber data yang digunakan dalam penelitian ini

1. Data Primer, yaitu data yang diperoleh dari tanggapan responden terhadap item pertanyaan yang diajukan dalam kuesioner.

2. Data Sekunder, yaitu data yang diperoleh dari dokumen-dokumen dan arsip Badan Kepegawaian Pengembangan Sumberdaya Manusia Kabupaten Bantaeng Provinsi Sulawesi Selatan yang ada kaitannya dengan penelitian ini.

e. Teknik Pengumpulan Data

Teknik yang digunakan dalam pengumpulan data dalam penelitian ini adalah sebagai berikut :

1. Observasi

Teknik pengumpulan data yang dilakukan melalui hasil pengamatan secara langsung pada obyek penelitian terutama mengenai motivasi, disiplin dan sarana prasarana terhadap kinerja pegawai melalui kepuasan kerja pegawai Badan Kepegawaian dan Pengembangan Sumber Daya Manusia Kabupaten Bantaeng Provinsi Sulawesi Selatan.

2. Questionare

Yaitu teknik pengumpulan data yang dilakukan dengan cara menyebarkan selebaran questionare (angket) untuk diisi kepada responden yang menjadi sampel dalam penelitian ini.

3. Dokumentasi

Dokumentasi yakni tehnik pengumpulan data yang dilakukan dengan cara mengumpulkan sejumah data-data tertulis, dokumen-dokumen penting baik yang berasal dari dalam organisasi maupun yang berasal dari sejumlah literatur dan bahan pustaka yang ada kaitannya dengan penelitian ini.

\section{f. Teknis Analisis Data}

Berdasarkan permasalahan dan hipotesis yang telah dikemukakan sebelumnya, dalam menguji kebenarannya maka digunakan teknik analisis data yaitu sebagai berikut:

1. Analisis kualitatif adalah suatu analisis yang memberikan gambaran atau menguraikan mengenai jawaban-jawaban responden atas item-item yang terdapat dalam kuesioner dan akan diolah dengan cara dikelompokkan dan ditabulasikan kemudian diberi penjelasan.

2. Analisis Regresi Berganda yaitu suatu analisis untuk melihat seberapa besar pengaruh motivasi, disiplin kerja dan sarana prasarana terhadap kinerja pegawai melalui kepuasan kerja pegawai dengan menggunakan rumus yang dikemukakan oleh Sugiyono (2016) yaitu :

$$
\begin{aligned}
& \mathrm{Y}=\beta 0+\beta 1 \mathrm{X} 1+\beta 2 \mathrm{X} 2+\beta 3 \mathrm{X} 3+\mathrm{e} \\
& \mathrm{Z}=\beta 0+\beta 1 \mathrm{X} 1+\beta 2 \mathrm{X} 2+\beta 3 \mathrm{X} 3+\beta 4 \mathrm{Z} 1+\mathrm{e} \ldots \ldots(1) \\
& \text { Dimana }: \quad \text { (2) } \\
& \mathrm{Z}=\text { Kinerja pegawai } \\
& \mathrm{Y} \quad=\text { Kepuasan kerja } \\
& \mathrm{X} 1=\text { Motivasi kerja pegawai } \\
& \mathrm{X} 2=\text { Disiplin kerja } \\
& \mathrm{X} 3=\text { Sarana Prasarana } \\
& \mathrm{Bo}=\text { Konstanta } \\
& \beta 1-\beta 4 \quad=\text { Koefisien regresi } \\
& \mathrm{e} \quad=\text { Tingkat kesalahan }
\end{aligned}
$$

3. Uji Validitas dan Reliabilitas

Pengembangan instrument ditempuh melalui beberapa cara, yaitu selain mendefinisikan operasional variabel penelitian, menyusun indikator variabel penelitian dan melakukan uji coba instrument, dalam penelitian harus melakukan pengujian validitas dan reliabilitas.

a. Uji Validitas

Uji validitas berguna untuk mengetahui apakah ada pertanyaan pada kuesioner yang harus dibuang/diganti yang dianggap tidak relevan, Umar (2013) Pengujian validitas dilakukan dengan cara menkorelasikan skor jawaban yang diperoleh pada setiap item dengan skor total dari keseluruhan item. Korelasi dihitung dengan menggunakan teknik korelasi Product Moment untuk mengetahui hubungan antar dua variabel.

b. Uji Reliabilitas

Uji realibilitas (keandalan) adalah ukuran suatu kestabilan dan konsistensi responden dalam menjawab hal yang berkaitan dengan konstrukkonstruk pertanyaan yang merupakan dimensi suatu variabel dan disusun dalam suatu bentuk kuesioner. Teknik dalam penelitian ini dengan menggunakan teknik Alpha Cronboach. Hasil perhitungan selanjutnya dibandingkan dengan angka koefisien r yaitu sebesar 0,60. Ghozali (2018) jika koefisien alpha lebih besar dari koefisien $r$ maka kuesioner dikatakan reliabel.

4. Uji Asumsi klasik

Uji asumsi klasik bertujuan untuk menguji apakah model regresi linear bebas dari adanya bias atau penyimpangan sehingga diperoleh regresi yang benar BLUE (Best Linier Unbiased Estimation), yang terdiri dari :

\section{a. Uji Multikolineritas}

Hasil uji multikolineritas menunjukkan besarnya nilai tolerance untuk semua variabel $>0,1$ dan nilai VIF masing-masing variabel $<10$ maka tidak terjadi multikolineritas.

b. Uji Heterokesdastisitas

Pengujian heterokesdastisitas dalam penelitian ini dilakukan dengan Glejser Test dengan pvalue masing-masing > 0,05, maka model regresi tidak terjadi heterokesdastisitas.

c. Uji Normalitas 
Pengujian normalitas dapat dilakukan dengan uji kosmogorov-smirnov test, hasil pengujian menunjukkan bahwa apabila pvalue atau signifikan $>$ nilai standar, maka data residual berdistribusi normal.

\section{HASIL DAN PEMBAHASAN}

1) Analisis Pengaruh Motivasi Kerja, Disiplin Kerja, Sarana dan Prasarana terhadap Kinerja Pegawai melalui Kepuasan kerja pada BKPSDM Kabupaten Bantaeng Provinsi Sulawesi Selatan

Analisis uji jalur bertujuan untuk mengetahui pengaruh motivasi kerja, disiplin kerja, sarana dan prasarana terhadap Kinerja Pegawai melalui Kepuasan kerja pada BKPSDM Kabupaten Bantaeng Provinsi Sulawesi Selatan, dimana dalam pelaksanaan analisis uji jalur dalam penelitian ini dilakukan dengan melakukan penyebaran kuesioner kepada pegawai dengan membagikan kuesioner kepada 56 orang pegawai pada BKPSDM Kabupaten Bantaeng Provinsi Sulawesi Selatan.

Berdasarkan hasil olahan data dalam penelitian ini dengan menggunakan SPSS Versi 23, sebelum dilakukan analisis pengaruh langsung dan pengaruh tidak langsung dalam penelitian ini maka akan disajikan hasil koefisien jalur dari setiap variabel dalam penelitian ini yakni pengaruh motivasi kerja, disiplin kerja, sarana dan prasarana terhadap kepuasan kerja (model 1), yang dapat disajikan melalui tabel berikut ini :

Tabel 1

Analisis Pengujian Regresi Model 1

\begin{tabular}{|c|c|c|c|}
\hline \multicolumn{4}{|c|}{ Coefficients $^{\mathrm{a}}$} \\
\hline \multirow[b]{2}{*}{ Model } & $\begin{array}{c}\text { Unstandardized } \\
\text { Coefficients }\end{array}$ & $\begin{array}{l}\text { Standardized } \\
\text { Coefficients }\end{array}$ & Sig. \\
\hline & $\begin{array}{lc} & \text { Std. } \\
\text { B } & \text { Error }\end{array}$ & Beta & \\
\hline $\begin{array}{ll} & \text { (Constant) } \\
\end{array}$ & .119 .185 & & $.643 \quad .523$ \\
\hline Motivasi Kerja & $.365 \quad .132$ & .346 & 2.761 .008 \\
\hline Disiplin Kerja & $.343 \quad .102$ & .361 & $3.351 \quad .002$ \\
\hline $\begin{array}{l}\text { Sarana dan } \\
\text { Prasarana Kerja }\end{array}$ & . $282 \quad .099$ & .281 & 2.863 .006 \\
\hline $\begin{array}{l}\mathrm{R} \\
163,472\end{array}$ & $=0,951$ & $\mathrm{~F}_{\text {hitung }}$ & $=$ \\
\hline Adjusted Rsquare & $=0,899$ & Sign & $=0,000$ \\
\hline
\end{tabular}

a. Dependent Variable: Kepuasan Kerja

Sumber : Data Primer diolah, 2021

Berdasarkan hasil olahan data yang sebagaimana telah disajikan melalui tabel 8 maka dapat disajikan persamaan regresi dalam penelitian ini yang dapat diuraikan sebagai berikut

$\mathrm{Y}=0,119+0,346 \mathrm{X}_{1}+0,361 \mathrm{X}_{2}+0,281 \mathrm{X}_{3} \ldots \ldots \ldots$..(5)

Dari persamaan di atas maka dapat diinterpretasikan atau dijelaskan dari persamaan regresi yang telah dikemukakan yaitu sebagai berikut :

1) Nilai Constanta $=0,119$, yang diartikan bahwa dengan adanya motivasi kerja, disiplin kerja, sarana dan prasarana, maka besarnya kepuasan kerja sebesar 0,119 .

2) $\quad \beta_{1} X_{1}=0,346$, dimana dapat diinterpretasikan bahwa setiap kenaikan 1 pont motivasi kerja maka dapat diikuti oleh adanya kepuasan kerja. Dimana dapat dikatakan bahwa semakin tinggi motivasi kerja maka dapat meningkatkan kepuasan kerja pegawai.

3) $\beta_{2} X_{2}=0,361$, menunjukkan bahwa setiap kenaikan 1 point mengenai disiplin kerja maka akan dapat meningkatkan kepuasan kerja sebesar 0,361. Semakin baik disiplin kerja yang dimiliki oleh pegawai maka dapat diikuti oleh adanya kepuasan kerja.

4) $B_{3} X_{3}=0,281$, menunjukkan bahwa setiap kenaikan 1 point mengenai sarana dan prasarana kerja maka akan dapat meningkatkan kepuasan kerja sebesar 0,281 . Semakin baik sarana dan prasarana kerja yang lengkap dan tersedia pada BKPSDM Kabupaten Bantaeng maka kepuasan kerja pegawai semakin meningkat.

Dalam kaitannya dengan uraian tersebut di atas maka dapat dikatakan bahwa motivasi kerja, disiplin dan sarana prasarana kerja memberikan pengaruh yang positif terhadap kepuasan kerja pegawai pada BKPSDM Kabupaten Bantaeng.

Kemudian dilihat dari nilai $\mathrm{R}=0,951$ yang dapat diartikan bahwa ada hubungan yang kuat antara motivasi kerja, disiplin, sarana dan prasarana terhadap kepuasan kerja. Sedangkan dilihat dari Adjusted $\mathrm{R}_{\text {square }}=0,899$, hal ini menunjukkan bahwa sebesar $89,90 \%$ variasi kepuasan kerja dapat dijelaskan oleh motivasi kerja, disiplin serta sarana dan prasarana kerja, sedangkan sisanya sebesar $10,1 \%(1-0,899)$ dijelaskan oleh faktor-faktor lain yang tidak dimasukkan dalam model penelitian ini.

Pengujian secara simultan yang dilihat dari $\mathrm{F}_{\text {hitung }}=$ 163,472 dan dengan nilai $\rho$ value $=0,000$, dimana dengan nilai $\rho$ value $=0,000<0,05$, yang menunjukkan bahwa model regresi dapat digunakan dalam memprediksi kepuasan kerja atau dapat dikatakan bahwa motivasi kerja, disiplin kerja, serta sarana dan prasarana kerja secara bersama-sama berpengaruh terhadap kepuasan kerja pegawai pada BKPSDM Kabupaten Bantaeng Provinsi Sulawesi Selatan. Setelah dilakukan pengujian secara serempak (Uji F) maka akan dilakukan pengujian secara parsial (Uji t) yang dapat diuraikan sebagai berikut:

\section{a. Pengaruh Motivasi Kerja Terhadap Kepuasan Kerja}

Hasil pengujian secara parsial yaitu pengaruh motivasi kerja terhadap kepuasan kerja maka diperoleh nilai pvalue $=0,008<0,05$, hal ini menunjukkan bahwa ada pengaruh positif dan signifikan motivasi kerja terhadap kepuasan kerja pegawai pada BKPSDM Kabupaten Bantaeng, yang dapat dikatakan bahwa semakin baik pemberian motivasi kerja maka akan dapat meningkatkan kepuasan kerja, sehingga dari hipotesis penelitian yang telah dikemukakan diterima/terbukti.
b. Pengaruh Disiplin Kerja Terhadap Kepuasan Kerja


Hasil pengujian secara parsial yaitu pengaruh disiplin kerja terhadap kepuasan kerja, diperoleh nilai ovalue $=0,002<0,05$, karena nilai $\rho v a l u e$ yang jauh dari 0,05 maka dapat dikatakan bahwa ada pengaruh positif dan signifikan disiplin kerja terhadap kepuasan kerja, yang dapat diindikasikan bahwa semakin baik disiplin kerja pegawai maka secara bermakna dapat meningkatkan kepuasan kerja pegawai.

\section{c. Pengaruh Sarana Dan Prasarana Terhadap Kepuasan Kerja}

Hasil pengujian secara parsial yaitu pengaruh sarana dan prasrana terhadap kepuasan kerja, diperoleh nilai pvalue $=0,006<0,05$, karena nilai pvalue yang jauh dari 0,05 maka dapat dikatakan bahwa ada pengaruh positif dan signifikan sarana dan prasarana terhadap kepuasan kerja, hal ini dapat diindikasikan bahwa semakin lengkap dan tersedia sarana dan prasarana kerja maka secara bermakna dapat meningkatkan kepuasan kerja pegawai.

Kemudian akan disajikan analisis regresi pengaruh motivasi kerja, disiplin kerja, sarana dan prasrana kerja, serta kepuasan kerja terhadap kinerja pegawai (model 2) pada BKPSDM Kabupaten Bantaeng Provinsi Sulawesi Selatan. Hal ini dapat disajikan hasil pengujian regresi model 2 yang dapat dilihat melalui tabel yaitu sebagai berikut :

\section{Tabel 2}

Analisis Pengujian Regresi Model 2

\begin{tabular}{|c|c|c|c|c|c|}
\hline \multirow[b]{2}{*}{ Model } & \multicolumn{2}{|c|}{$\begin{array}{c}\text { Unstandardized } \\
\text { Coefficients } \\
\end{array}$} & \multirow{2}{*}{$\begin{array}{c}\begin{array}{c}\text { Standardized } \\
\text { Coefficients }\end{array} \\
\text { Beta } \\
\end{array}$} & \multirow[t]{2}{*}{$\mathrm{t}$} & \multirow[t]{2}{*}{ Sig. } \\
\hline & $\mathrm{B} \quad \mathrm{t}$ & td. Error & & & \\
\hline 1 (Constant) & .329 & .132 & & 2.502 & .016 \\
\hline Motivasi Kerja & .211 & .100 & .207 & 2.100 & .041 \\
\hline Disiplin Kerja & .166 & .080 & .182 & 2.080 & .043 \\
\hline $\begin{array}{l}\text { Sarana dan } \\
\text { Prasarana Kerja }\end{array}$ & .294 & .075 & .305 & 3.917 & .000 \\
\hline Kepuasan Kerja & .307 & .098 & .318 & 3.119 & .003 \\
\hline $\mathrm{R}$ & $=0,974$ & & Fhitung & $=237$, & \\
\hline R Square & $=0,949$ & & Sign. & $=0,00$ & \\
\hline \multicolumn{6}{|c|}{ Adjusted R Square $=0,945$} \\
\hline Dependent Varia & ble: Kine & erja Pes & & & \\
\hline
\end{tabular}

Tabel 2 yaitu hasil pengujian regresi model 2 mengenai analisis pengaruh motivasi kerja, disiplin kerja, sarana dan prasarana kerja, serta kepuasan kerja terhadap kinerja pegawai (model 2) pada BKPSDM Kabupaten Bantaeng Provinsi Sulawesi Selatan, maka dapat disajikan persamaan regresi untuk model 2 yaitu :

$Z=0,329+0,207 X_{1}+0,182 X_{2}+0,305 X_{3}+0,318_{Z}$

Berdasarkan persamaan regresi yang telah disajikan di atas maka dapat disajikan interpretasi dari persamaan regresi dalam penelitian ini yang dapat diuraikan sebagai berikut :

1) Nilai konstanta $=0,329$, dapat diartikan bahwa jika motivasi kerja, disiplin kerja, sarana dan prasarana kerja, serta kepuasan kerja dianggap konstan maka besarnya kinerja pegawai sebesar 0,329.

2) $\beta_{1} X_{1}=0,207$, menyatakan bahwa setiap kenaikan 1 pont motivasi kerja dapat diikuti oleh adanya peningkatan kinerja pegawai sebesar 0,207 . Semakin baik pemberian motivasi kerja maka akan semakin meningkat pula kinerja pegawai pada BKPSDM Kabupaten Bantaeng Provinsi Sulawesi Selatan.

3) $\beta_{2} X_{2}=0,182$, diartikan bahwa setiap kenaikan 1 point disiplin kerja dapat diikuti oleh adanya kenaikan kinerja pegawai pada BKPSDM Kabupaten Bantaeng Provinsi Sulawesi Selatan.

4) $\beta_{3} X_{3}=0,305$, yang diartikan bahwa setiap kenaikan 1 point sarana dan prasrana kerja dapat diikuti oleh adanya kenaikan kinerja pegawai pada BKPSDM Kabupaten Bantaeng Provinsi Sulawesi Selatan.

5) $\quad \beta_{3} Z=0,318$. menyatakan bahwa setiap kenaikan 1 point kepuasan kerja, dapat diikuti oleh adanya peningkatan kinerja pegawai sebesar 0,318 . Hal ini dapat dikatakan bahwa semakin tinggi kepuasan kerja yang dirasakan oleh pegawai, maka akan semakin meningkat pula kinerja pegawai.

Berdasarkan interpretasi dari persamaan regresi yang telah diuraikan di atas, maka dapat dikatakan bahwa motivasi kerja, disiplin kerja, sarana dan prasarana kerja serta kepuasan kerja memiliki kontribusi dalam meningkatkan kinerja pegawai pada BKPSDM Kabupaten Bantaeng Provinsi Sulawesi Selatan. Sedangkan dalam tabel 4.17 maka besarnya nilai $R=0,974$, hal ini dapat dikatakan bahwa ada hubungan yang kuat antara motivasi kerja, disiplin kerja, sarana dan prasarana kerja serta kepuasan kerja terhadap kinerja pegawai pada BKPSDM Kabupaten Bantaeng Provinsi Sulawesi Selatan. Sedangkan nilai Adjusted $\mathbf{R}_{\text {square }}=0,945$, yang artinya 94,5\% variasi kinerja pegawai dapat dijelaskan oleh motivasi kerja, disiplin kerja, sarana dan prasarana kerja serta kepuasan kerja, sedangkan sisanya yaitu sebesar $5,5 \%(100 \%-94,50 \%)$ dijelaskan oleh sebab-sebab yang lain di luar dari model penelitian ini.

Kemudian pengujian $\mathrm{F}_{\text {test }}$ dalam uji anova didapat dari nilai $F_{\text {hitung }}=237,726$ dan nilai $\rho$ value $=0,000$, karena dengan nilai pvalue $=0,000<0,05$, hal ini menunjukkan bahwa model regresi dapat digunakan dalam memprediksi kinerja pegawai. Atau dengan kata lain bahwa motivasi kerja, disiplin kerja, sarana dan prasarana kerja serta kepuasan kerja secara bersama-sama berpengaruh terhadap kinerja pegawai. Selanjutnya akan disajikan uji parsial (Uji t), yang dapat diuraikan sebagai berikut :

1. Pengaruh motivasi kerja terhadap kinerja pegawai

Besarnya nilai $t_{\text {hitung }}=2,100$ dan pvalue $=0,041$, karena dengan nilai $\rho v a l u e=0,041<0,05$. Hal ini menunjukkan ada pengaruh positif dan signifikan motivasi kerja terhadap kinerja pegawai, dimana motivasi kerja dapat memberikan pengaruh yang bermakna dalam meningkatkan kinerja pegawai.

2. Pengaruh disiplin kerja terhadap kinerja pegawai

Besarnya nilai $\mathrm{t}_{\text {hitung }}=2,080$ dan pvalue $=0,043$, dengan nilai $\rho$ value $=0,043$ yang lebih kecil dari 0,05 maka dapat dikatakan bahwa ada pengaruh positif dan signifikan disiplin kerja terhadap kinerja 
pegawai, yang dapat diindikasikan bahwa semakin baik disiplin kerja maka akan memberikan pengaruh yang bermakna dalam meningkatkan kinerja pegawai pada BKPSDM Kabupaten Bantaeng Provinsi Sulawesi Selatan.

3. Pengaruh sarana dan prasarana terhadap kinerja pegawai

Besarnya nilai $\mathrm{t}_{\text {hitung }}=3,917$ dan nilai $\rho$ value $=0,000$, dimana dengan nilai pvalue $=0,000<0,05$ maka dapat dikatakan bahwa sarana dan prasarana berpengaruh positif dan signifikan terhadap kinerja pegawai. Dimana dapat dikatakan bahwa sarana dan prasarana memberikan pengaruh yang bermakna dalam meningkatkan kinerja pegawai pada BKPSDM Kabupaten Bantaeng Provinsi Sulawesi Selatan.

Berdasarkan hasil analisis regresi model 1 dan model 2, yang telah diuraikan maka dapat dilakukan analisis uji jalur untuk pengujian hipotesis penelitian, namun sebelumnya akan disajikan gambar uji jalur yang dapat dilihat melalui gambar 1 yaitu sebagai berikut :

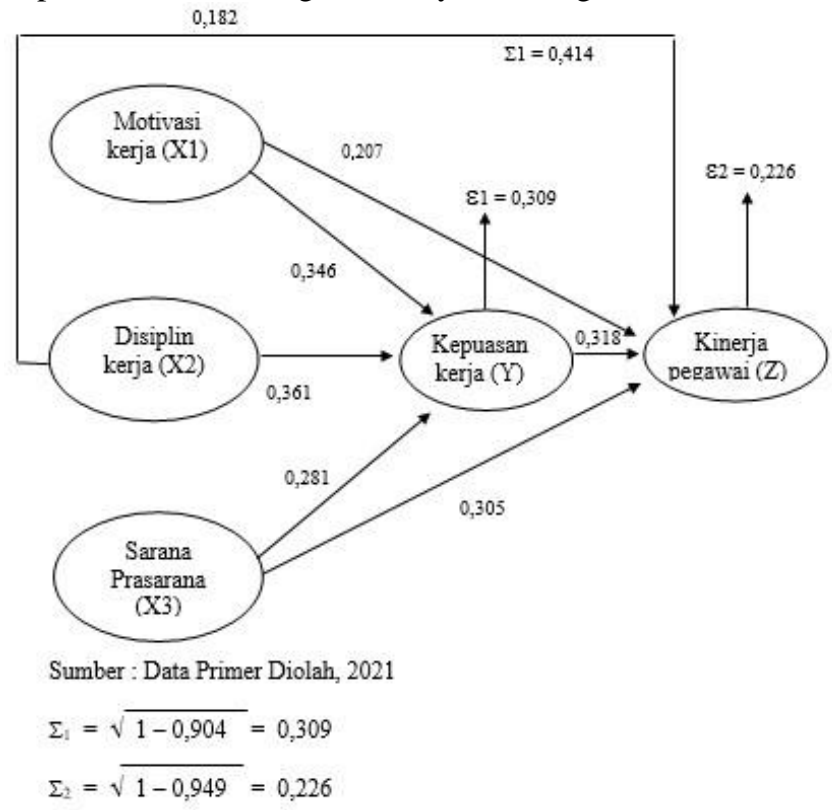

Gambar 1. Hasil Uji Jalur Pengaruh Motivasi Kerja, Disiplin Kerja, Sarana Dan Prasarana, Dan Kepuasan Kerja Terhadap Kinerja Pegawai

Berdasarkan gambar uji jalur maka dapat dilakukan hasil analisis mengenai pengaruh motivasi kerja, disiplin kerja, sarana dan prasarana terhadap kinerja pegawai melalui kepuasan kerja sebagai variabel mediasi. Sehingga dalam analisis data penelitian ini akan dilakukan hasil uji pengaruh tidak langsung dari setiap variabel dalam penelitian ini yang dapat diuraikan sebagai berikut :
1. Pengaruh Motivasi Kerja Terhadap Kinerja Pegawai Melalui Kepuasan Kerja
Sebelum dilakukan uji jalur pengaruh motivasi kerja terhadap kinerja pegawai dengan kepuasan kerja sebagai variabel mediasi, terlebih dahulu akan disajikan gambar uji jalur yang dapat disajikan melalui Gambar 2 yaitu :

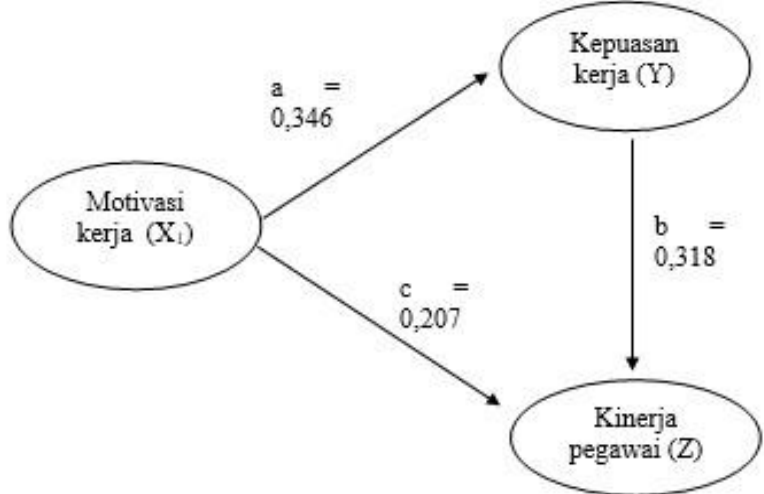

Gambar 2. Analisis Uji Jalur Pengaruh Motivasi Kerja

Terhadap Kinerja Pegawai Melalui Kepuasan Kerja

Berdasarkan Gambar 2 yaitu uji jalur maka dapat diketahui bahwa besarnya pengaruh langsung motivasi kerja terhadap kinerja pegawai sebesar 0,207 atau $20,70 \%$, sedangkan besarnya pengaruh tidak langsung motivasi kerja terhadap kinerja pegawai melalui kepuasan kerja sebesar $11 \%$ atau $(0,346 \times 0,318 \times 100)$. Sehingga besarnya total pengaruh motivasi kerja terhadap kinerja pegawai melalui kepuasan kerja pegawai pada BKPSDM Kabupaten Bantaeng Provinsi Sulawesi Selatan sebesar 0,317 atau $31,70 \%(0,207+0,110 \times 100)$.

Untuk dapat membuktikan bahwa kepuasan kerja dapat memediasi pengaruh motivasi kerja terhadap kinerja pegawai pada BKPSDM Kabupaten Bantaeng Provinsi Sulawesi Selatan maka digunakan uji sobel test. Dengan menggunakan kalkulator sobel test secara online yang dapat disajikan melalui Tabel 3 yaitu sebagai berikut :

Tabel 3. Hasil Uji Sobel Test Pengaruh Motivasi Kerja

Terhadap Kinerja Pegawai Melalui Kepuasan Kerja

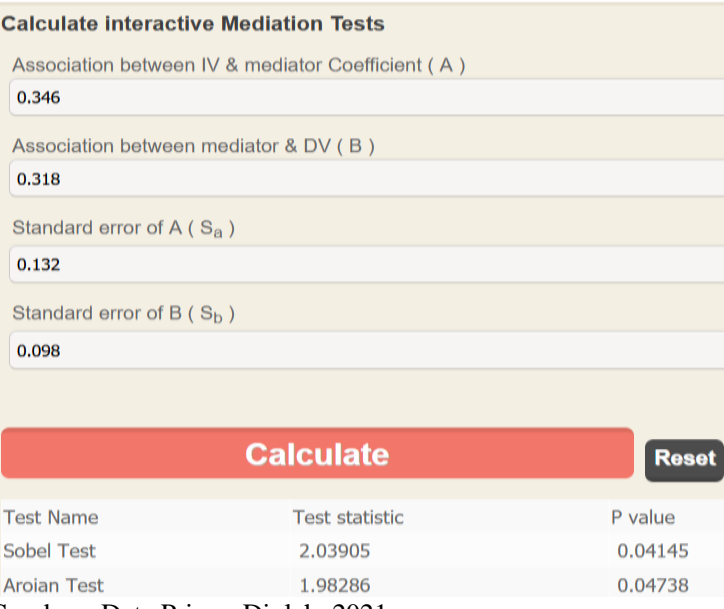

Sumber : Data Primer Diolah, 2021

Tabel 3 yakni hasil uji sobel test secara online, nampak bahwa nilai sobel test statistic sebesar 2,039 dan pvalue $=0,041$, karena nilai sobel test statistik sebesar $2,039>1,96$ dan pvalue $=0,041<0,05$ maka dapat dikatakan bahwa kepuasan kerja dapat memediasi secara parsial pengaruh motivasi kerja terhadap kinerja pegawai. Dimana dengan adanya motivasi kerja maka akan dapat memberikan pengaruh yang bermakna dalam memberikan 
kepuasan kerja sehingga berimplikasi terhadap kinerja pegawai.

\section{Pengaruh Disiplin Kerja Terhadap Kinerja Pegawai Melalui Kepuasan Kerja}

Sebelum dilakukan perhitungan pengaruh tidak langsung dalam uji jalur, maka terlebih dahulu akan disajikan gambar uji jalur pengaruh disiplin kerja terhadap kinerja pegawai melalui kepuasan kerja pada BKPSDM Kabupaten Bantaeng Provinsi Sulawesi Selatan yaitu :

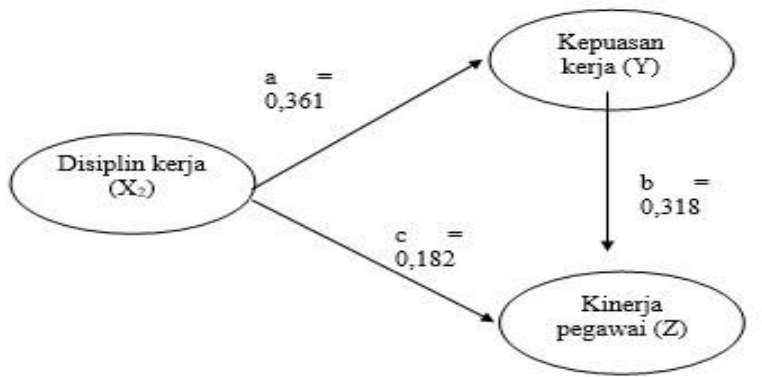

Gambar 3

Analisis Uji Jalur Pengaruh Disiplin Kerja Terhadap Kinerja Pegawai Melalui Kepuasan Kerja Sumber : Data Primer, 2021

Gambar 3 yaitu uji jalur pengaruh disiplin kerja terhadap kinerja pegawai melalui kepuasan kerja pada BKPSDM Kabupaten Bantaeng Provinsi Sulawesi Selatan maka besarnya pengaruh langsungnya sebesar 0,182 atau $18,20 \%$. Sedangkan besarnya pengaruh tidak langsungnya sebesar 0,115 atau $12,50 \%$, sehingga total pengaruhnya sebesar $29,70 \%(0,182+0,115 \times 100)$.

Kemudian akan dilakukan pengujian pengaruh disiplin kerja terhadap kinerja pegawai melalui kepuasan kerja menggunakan analisis sobel test secara online yang dapat disajikan melalui Tabel 4 berikut ini :

Tabel 4. Hasil Perhitungan Sobel Test Secara Online Pengaruh Disiplin Kerja Terhadap Kinerja Pegawai Melalui Kepuasan Kerja

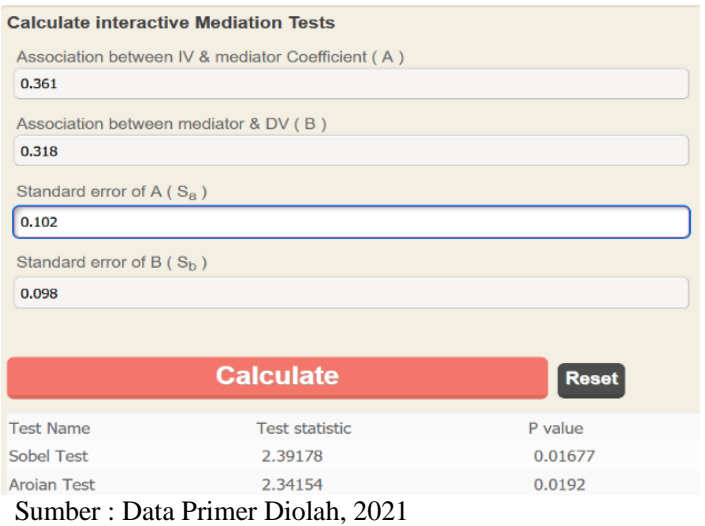

Tabel 4 yaitu hasil perhitungan sobel test pengaruh disiplin kerja terhadap kinerja pegawai melalui kepuasan kerja, dimana diperoleh nilai sobel test statistic sebesar 2,391 dan pvalue $=0,016$, karena nilai sobel test statistik sebesar 2,391 > 1,96 dan pvalue $=0,016<0,05$, hal ini membuktikan bahwa kepuasan kerja dapat memediasi secara parsial pengaruh disiplin kerja terhadap kinerja pegawai. Penelitian ini dapat diartikan bahwa dengan adanya disiplin kerja yang dimiliki oleh setiap pegawai maka akan dapat memberikan pengaruh yang bermakna dalam meningkatkan kepuasan kerja sehingga berdampak pada kinerja pegawai.

3. Pengaruh Sarana Dan Prasarana Terhadap Kinerja Pegawai Melalui Kepuasan Kerja

Untuk memperoleh hasil perhitungan pengaruh tidak langsung dalam uji jalur, maka terlebih dahulu akan disajikan gambar uji jalur pengaruh sarana dan prasarana terhadap kinerja pegawai melalui kepuasan kerja pada BKPSDM Kabupaten Bantaeng Provinsi Sulawesi Selatan yaitu :

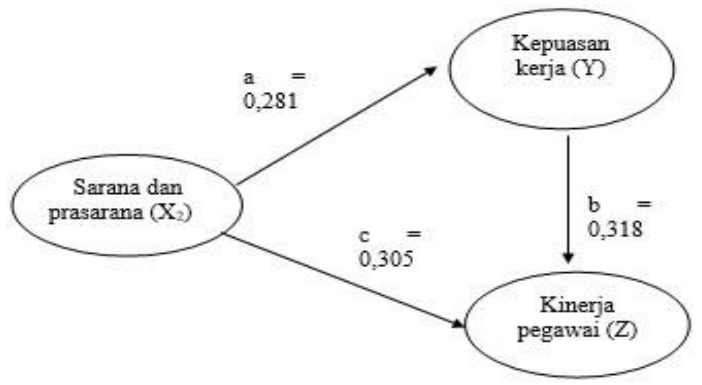

Gambar 4. Analisis Uji Jalur Pengaruh Sarana Dan Prasarana Terhadap Kinerja Pegawai Melalui Kepuasan Kerja

Sumber : Data Primer, 2021

Gambar 4 yaitu uji jalur pengaruh sarana dan prasarana terhadap kinerja pegawai melalui kepuasan kerja pada BKPSDM Kabupaten Bantaeng Provinsi Sulawesi Selatan maka besarnya pengaruh langsungnya sebesar 0,305 atau $30,50 \%$. Sedangkan besarnya pengaruh tidak langsungnya sebesar 0,089 atau 8,90\%, sehingga total pengaruhnya sebesar $39,40 \%(0,305+0,089 \times 100)$.

Kemudian akan dilakukan pengujian pengaruh sarana dan prasarana terhadap kinerja pegawai melalui kepuasan kerja dengan analisis sobel test secara online yang dapat disajikan melalui Tabel 5. berikut ini :

Tabel 5. Hasil Perhitungan Sobel Test Pengaruh Sarana

Dan Prasarana Terhadap Kinerja Pegawai Melalui

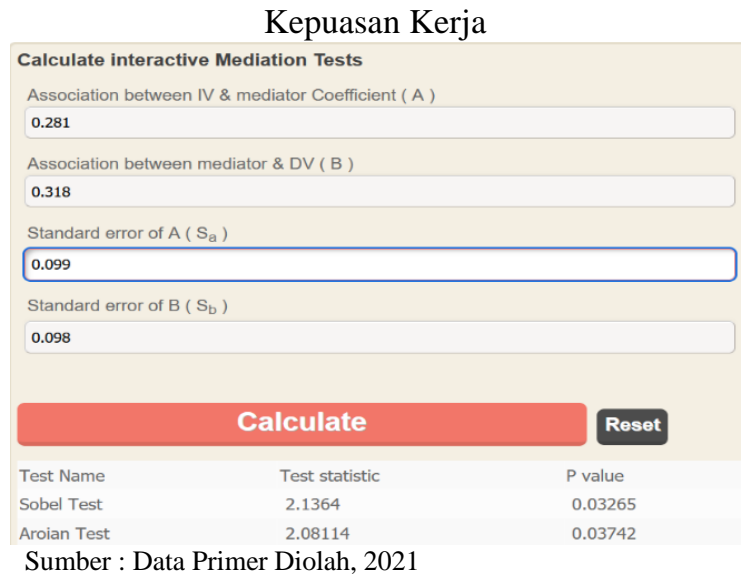




\section{2) Pengaruh motivasi kerja terhadap kepuasan kerja}

Hasil analisis data dalam penelitian ini yakni pengaruh motivasi kerja terhadap kepuasan kerja, dimana dalam penelitian yang telah dilakukan menemukan bahwa motivasi kerja memberikan pengaruh positif dan signifikan terhadap kepuasan kerja, ini berarti bahwa semakin tinggi motivasi kerja maka akan dapat memberikan pengaruh yang bermakna dalam meningkatkan kepuasan kerja pegawai pada BKPSDM Kabupaten Bantaeng Provinsi Sulawesi Selatan. Hal ini sesuai dengan teori yang dikemukakan oleh Ansory, dkk (2018) bahwa motivasi adalah konsep yang menguraikan tentang kekuatan-kekuatan yang ada dalam diri setiap individu untuk memulai dan mengarahkan perilaku. Konsep ini digunakan untuk menjelaskan perbedaanperbedaan dalam intensitas perilaku dimana perilaku yang bersemangat adalah hasil dari tingkat motivasi yang kuat. Artinya semakin baik motivasi yang diberikan kepada pegawai maka kepuasan kerja pegawai akan semakin meningkat.

Berdasarkan hasil penyebaran kuesioner kepada pegawai maka dalam penelitian ini dilihat dari motivasi kerja sudah dikategorikan baik, hal ini didasari dari persepsi pegawai yang memberikan kontribusi tertinggi mengenai kondisi kerja saat ini, memberikan kenyamanan dan dapat mendukung pegawai dalam menjalankan aktivitas kerja sehari-hari, dimana BKPSDM Kabupaten Bantaeng selalu memberikan kenyamanan bagi pegawai dalam bekerja dengan memperhati-kan kondisi kerja, kemudian Organisasi menyediakan fasilitas kerja, sehingga dapat menunjang kelancaran pegawai dalam mengerjakan pekerjaannya, fasilitas kerja yang disiapkan adalah komputer, printer dan wifi. Begitu pula bahwa pimpinan senantiasa menuntut agar pegawai dapat menghasilkan prestasi kerja yang tinggi, ini dapat dilihat bahwa BKPSDM Kabupaten Bantaeng selalu memberikan penghargaan bagi setiap pegawai yang memiliki prestasi kerja di atas rata-rata. Kemudian pegawai merasa senang, bila pengabdian selama bekerja di organisasi ini mendapat pengakuan dari pimpinan, ini dapat dilihat bahwa pimpinan tidak segan-segan memberikan pengakuan kepada pegawai yang berprestasi. Namun indikator yang memberikan kontribusi terendah mengenai balas jasa yang diterima dalam bentuk gaji dan tunjangan kinerja menjadi motivasi bagi pegawai untuk bekerja lebih giat lagi, hal ini perlu diperhatikan oleh kepala BKPSDM agar perlu meninjau kembali gaji dan tunjangan kinerja bagi setiap pegawai, agar hal ini menjadi pendorong bagi pegawai untuk bekerja lebih giat lagi.

Hasil kesimpulan yang diperoleh bahwa motivasi kerja secara keseluruhan sudah dapat memberikan pengaruh terhadap kepuasan kerja pegawai pada BKPSDM Kabupaten Bantaeng Provinsi Sulawesi Selatan. Penelitian ini sejalan dengan penelitian yang dilakukan oleh Maharjan (2012) dan Shah et al. (2012) yang menyatakan bahwa motivasi berpengaruh positif terhadap kepuasan kerja.

\section{3) Pengaruh Disiplin Kerja Terhadap Kepuasan Kerja}

Berdasarkan analisis persamaan regresi maka diperoleh hasil temuan bahwa disiplin kerja berpengaruh positif dan signifikan terhadap kepuasan kerja pegawai pada BKPSDM Kabupaten Bantaeng Provinsi Sulawesi Selatan. Hal ini sejalan dengan teori yang dikemukakan oleh Hasibuan (2019) bahwa kedisplinan adalah keadaan dan kesediaan seseorang men taati semua peraturan dan norma-norma sosial yang berlaku. Disiplin yang terbentuk dalam diri pekerja merupakan cerminan tanggungjawab seseorang dalam menjalankan tugas dan pekerjaannya sehingga dapat mendorong semangat kerja, kepuasan kerja dalam pencapaian tujuan organisasi.

Hasil penyebaran kuesioner maka diperoleh persepsi responden bahwa disiplin kerja sudah berada dalam kategori baik atau tinggi, hal ini dapat dilihat bahwa tujuan dan pekerjaan yang dibebankan sudah sesuai dengan kemampuan yang dimiliki pegawai, setiap pegawai merasa bahwa pimpinan dapat dijadikan teladan dan panutan oleh para bawahannya, kemudian Pimpinan selalu melakukan pengawasan melekat (waskat) kepada setiap pegawai sehingga berdampak pada kedisiplinan pegawai. Begitu pula bahwa setiap pegawai setuju bahwa dengan

diterapkan ikut mempengaruhi baik/buruknya kedisiplinan pegawai, serta setiap pegawai merasa bahwa kedisiplinan pegawai akan tercipta apabila hubungan kemanusiaan dalam instansi berjalan dengan baik, dan hal ini memberikan pengaruh terhadap kepuasan kerja pegawai pada BKPSDM Kabupaten Bantaeng Provinsi Sulawesi Selatan. Penelitian ini sejalan dengan penelitian yang dilakukan oleh Sukirman (2011) bahwa kepuasan kerja dan disiplin kerja pegawai memiliki adanya hubungan yang positif. Hal ini berarti, semakin tinggi tingkat kedisiplinan pegawai, maka kepuasan pegawai akan semakin meningkat. Sebaliknya, semakin rendah tingkat kedisiplinan pegawai, maka kepuasan pegawai akan semakin menurun.

\section{4) Pengaruh Sarana Dan Prasarana Terhadap Kepuasan Kerja}

Dari hasil analisis regresi linear berganda maka diperoleh hasil temuan bahwa sarana dan prasarana berpengaruh positif dan signifikan terhadap kepuasan kerja pegawai pada BKPSDM Kabupaten Bantaeng Provinsi Sulawesi Selatan. Hal ini sejalan dengan teori yang dikemukakan oleh Nurinaya (2017) bahwa sarana prasarana berfungsi untuk: mempercepat proses pelaksanaan pekerjaan sehingga dapat menghemat waktu, meningkatkan produktivitas baik barang maupun jasa, hasil kerja lebih berkualitas dan terjamin, lebih memudahkan dalam gerak para pengguna, ketetapan susunan stabilitas pekerjaan lebih terjamin, dan menimbulkan rasa nyaman dan rasa puas bagi orangorang yang berkepentingan dan menggunakannya. 
Hasil penyebaran kuesioner maka diperoleh temuantemuan bahwa sarana dan prasraana kerja yang ada pada BKPSDM Kabupaten Bantaeng sudah dipersepsikan baik oleh pegawai, hal ini dapat dilihat bahwa kondisi bangunan kantor kuat dengan dilengkapi ventilasi sehingga memberikan kenyamanan dalam bekerja, Sarana dan prasarana pendukung pekerjaan tersedia dan lengkap sehingga memberikan kepuasan bagi pegawai dalam bekerja. Kemudian setiap pegawai mampu menyelesaikan pekerjaan dengan kondisi peralatan kerja yang sesuai dengan jenis pekerjaan yang dilaksanakan, serta bagi pegawai bahwa penggunaan barang-barang kantor atau peralatan kerja sangat sesuai untuk mendukung kinerja pegawai. Sehingga dapat disimpulkan bahwa sarana dan prasarana yang ada pada BKPSDM Kabupaten Bantaeng Provinsi Sulawesi Selatan dapat memberikan kepuasan kerja bagi setiap pegawai. Penelitian Rustam (2012) hasil temuan bahwa sarana prasarana berpengaruh positif dan signifikan terhadap kepuasan kerja, dimana sarana dan prasarana sangat memberi dampak yang besar terhadap keberhasilan guru dalam menyampaikan materi, selain keberhasilan dalam menyampaikan materi juga akan mengarah kepada kepuasan kerja.

\section{5) Pengaruh Kepuasan Kerja Terhadap Kinerja Pegawai}

Berdasarkan hasil olahan data persamaan regresi maka diperoleh hasil bahwa kepuasan kerja berpengaruh positif dan signifikan terhadap kinerja pegawai pada BKPSDM Kabupaten Bantaeng Provinsi Sulawesi Selatan. Hal ini sesuai dengan teori yang dikemukakan oleh Handoko (2014) bahwa kepuasan kerja (job satisfaction) adalah keadaan emosional yang menyenangkan atau tidak menyenangkan dengan mana para pegawai memandang pekerjaan mereka. Kepuasan kerja mencerminkan perasaan seseorang terhadap pekerjaannya. Apabila pegawai puas maka akan nampak dalam sikap positif pegawai terhadap pekerjaannya untuk lebih meningkatkan kinerja kerjanya.

Dari persepsi pegawai maka diperoleh temuantemuan bahwa kepuasan kerja sudah berada dalam kategori baik atau tinggi, ini berarti bahwa rata-rata pegawai pada BKPSDM Kabupaten Bantaeng Provinsi Sulawesi Selatan merasa puas dalam menjalankan aktivitas kerja sehari-hari sehingga berdampak pada kinerja pegawai. Hasil temuan bahwa setiap pegawai merasa puas dengan pe-kerjaan yang ditangani selama ini karena sesuai dengan kompetensi yang dimiliki, kemudian pegawai merasa puas dengan upah/gaji yang diterima karena dapat memenuhi kebutuhan hidup bersama keluarga, setiap pegawai mempunyai kesempatan untuk mendapatkan promosi jabatan yang lebih tinggi sehingga pegawai merasakan kepuasan dalam bekerja pada organisasi ini. Begitu pula bahwa pengawasan yang dilaksanakan selama ini yaitu memonitoring aktivitas kerja pegawai memberikan kepuasan kerja bagi pegawai, serta Rekan kerja sangat mendukung dalam penyelesaian pekerjaan sehari-hari di kantor. Sehingga dengan adanya perasaan puas pegawai dalam bekerja maka berdampak terhadap peningkatan kinerja pegawai. Hasil penelitian ini relevan dengan penelitian yang dilakukan oleh Parwanto dan Wahyudin (2011), yang memperoleh hasil bahwa kepuasan kerja memiliki pengaruh signifikan terhadap kinerja pegawai.

\section{6) Pengaruh Motivasi Kerja Terhadap Kinerja Pegawai Melalui Kepuasan Kerja}

Hasil uji sobel test maka diperoleh hasil penelitian bahwa kepuasan kerja dapat memediasi pengaruh antara motivasi kerja terhadap kinerja pegawai pada BKPSDM Kabupaten Bantaeng Provinsi Sulawesi Selatan. Hal ini sesuai dengan teori Hasibuan (2019) bahwa motivasi adalah pemberian daya penggerak yang menciptakan kegairahan kerja seseorang, agar mereka mau bekerja sama, bekerja efektif dan terintegrasi dengan segala daya upayanya untuk mencapai kepuasan.

Berdasarkan hasil skor jawaban responden saat dilakukan pengisian kuesioner oleh pegawai, dimana skor jawaban tertinggi adalah kondisi kerja saat ini, memberikan kenyamanan dan dapat mendukung pegawai dalam menjalankan aktivitas kerja sehari-hari, agar diharapkan dapat lebih memperhatikan kondisi kerja sehingga pegawai merasa nyaman dalam bekerja dan memberikan hasil kerja yang maksimal. Sedangkan skor jawaban terendah adalah balas jasa yang diterima pegawai dalam bentuk gaji dan tunjangan kinerja menjadi motivasi untuk bekerja lebih giat lagi, sehingga hal ini perlu diperhatikan oleh BKPSDM Kabupaten Bantaeng untuk lebih memperhatikan masalah pemberian tunjangan-tunjangan kinerja pegawai. Penelitian Murti dan Srimulyani (2013) yang menyatakan bahwa terdapat hubungan mediasi antara motivasi kerja terhadap kinerja pegawai melalui kepuasan kerja.

\section{7) Pengaruh Disiplin Kerja Terhadap Kinerja Pegawai Melalui Kepuasan Kerja}

Berdasarkan hasil uji sobel test maka diperoleh hasil analisis regresi bahwa kepuasan kerja memediasi pengaruh disiplin kerja terhadap kinerja pegawai pada BKPSDM Kabupaten Bantaeng Provinsi Sulawesi Selatan. Hasil penyebaran kuesioner maka diperoleh temuan-temuan bahwa indikator yang memberikan kontribusi terendah terkait dengan disiplin kerja adalah tujuan dan pekerjaan yang dibebankan harus sesuai dengan kemampuan yang dimiliki pegawai, ini perlu menjadi perhatian BKPSDM Kabupaten Bantaeng agar tujuan dan pekerjaan yang dibebankan kepada pegawai maka terlebih dahulu harus disesuaikan dengan kemampuan yang dimiliki oleh pegawai dalam menjalankan aktivitas kerja sehari-hari.

Kemudian indikator yang memberikan kontribusi tertinggi adalah setiap pegawai merasa bahwa pimpinan dapat dijadikan teladan dan panutan oleh para bawahannya, ini diharapkan dapat dipertahankan oleh pimpinan BKPSDM Kabupaten Bantaeng karena keberhasilan suatu organisasi dalam mencapai visi dan misi yang ditetapkan adalah tergantung pada 
pimpinannya. Penelitian Filliantoni, dkk. (2019) menemukan bahwa kepuasan kerja dapat memediasi pengaruh kedisiplinan terhadap kinerja pegawai.

\section{8) Pengaruh Sarana Dan Prasarana Terhadap} Kinerja Pegawai Melalui Kepuasan Kerja

Berdasarkan hasil uji sobel test maka diperoleh hasil bahwa kepuasan kerja dapat memediasi pengaruh sarana dan prasarana terhadap kinerja pegawai. Dimana temuan dalam penelitian bahwa indikator yang memberikan kontribusi tertinggi adalah bagi pegawai, penggunaan barang-barang kantor atau peralatan kerja sangat sesuai untuk mendukung kinerja pegawai, sehingga hal ini harus dipertahankan karena dengan adanya penggunaan barangbarang kantor atau peralatan kerja maka akan memudahkan pegawai dalam menyelesaikan setiap pekerjaan yang diberikan. Sedangkan indikator yang memberikan kontribusi terendah adalah kondisi bangunan kantor kuat dengan dilengkapi ventilasi sehingga memberikan kenya-manan dalam bekerja, diharapkan dapat ditingkatkan yakni dengan melakukan renovasi dan desain tata kantor dengan melengkapi ventilasi. Penelitian Putro (2013) hasil temuan bahwa ada hubungan positif antara kinerja dengan sarana dan prasarana melalui kepuasan kerja pegawai.

\section{KESIMPULAN DAN SARAN}

Hasil penelitian dapat disimpulkan sebagai berikut:

a. Pengaruh motivasi kerja terhadap kepuasan kerja pegawai pada BKPSDM Kabupaten Bantaeng Provinsi Sulawesi Selatan, maka dapat disimpulkan bahwa motivasi kerja dengan indikator balas jasa, kondisi kerja, fasilitas kerja, prestasi kerja dan pengakuan dari atasan mempunyai pengaruh yang positif dan signifikan terhadap kepuasan kerja. Hal ini berarti bahwa dengan adanya motivasi kerja maka akan dapat meningkatkan kepuasan kerja pegawai pada BKPSDM Kabupaten Bantaeng Provinsi Sulawesi Selatan.

b. Pengaruh disiplin kerja terhadap kepuasan kerja pada BKPSDM Kabupaten Bantaeng Provinsi Sulawesi Selatan, yang menunjukkan bahwa disiplin kerja dengan indikator tujuan dan kemampuan, teladan pimpinan, pengawasan melekat (Waskat), sanksi dan hubungan kemanusiaan yang tergabung dalam variabel disiplin kerja mempunyai pengaruh yang positif dan signifikan terhadap kepuasan kerja pegawai.

c. Pengaruh sarana dan prasarana terhadap kepuasan kerja pada BKPSDM Kabupaten Bantaeng Provinsi Sulawesi Selatan, menunjukkan bahwa sarana dan prasarana dengan indikator: kondisi bangunan, ketersediaan sarana, kondisi sarana prasarana dan penggunaan peralatan kerja mempunyai pengaruh positif dan signifikan terhadap kepuasan kerja pegawai. Ini berarti bahwa semakin baik sarana dan prasarana kantor maka dapat memberikan pengaruh yang bermakna dalam meningkatkan kepuasan kerja pegawai.

d. Pengaruh kepuasan pegawai terhadap kinerja pegawai pada BKPSDM Kabupaten Bantaeng Provinsi Sulawesi Selatan, yang menemukan bahwa secara empiris kepuasan kerja pegawai dengan indikator : pekerjaan, upah, promosi jabatan, pengawas (supervise) dan rekan kerja memberikan pengaruh yang positif dan signifikan terhadap kinerja pegawai pada BKPSDM Kabupaten Bantaeng Provinsi Sulawesi Selatan.

e. Pengaruh motivasi kerja terhadap kinerja pegawai melalui kepuasan kerja, dimana dari hasil analisis melalui uji mediasi menemukan bahwa kepuasan kerja dapat memediasi secara parsial pengaruh motivasi kerja terhadap kinerja pegawai pada BKPSDM Kabupaten Bantaeng Provinsi Sulawesi Selatan.

f. Pengaruh disiplin kerja terhadap kinerja pegawai melalui kepuasan kerja, dimana dari hasil analisis melalui uji mediasi menemukan bahwa kepuasan kerja dapat memediasi secara parsial pengaruh disiplin kerja terhadap kinerja pegawai pada BKPSDM Kabupaten Bantaeng Provinsi Sulawesi Selatan.

g. Pengaruh sarana dan prasarana terhadap kinerja pegawai melalui kepuasan kerja, dimana dari hasil analisis melalui uji mediasi menemukan bahwa kepuasan kerja dapat memediasi secara parsial pengaruh sarana dan prasarana terhadap kinerja pegawai pada BKPSDM Kabupaten Bantaeng Provinsi Sulawesi Selatan.

\section{DAFTAR PUSTAKA}

Ansory, H. A. F., \& Indrasari, M. 2018. Manajemen Sumber Daya Manusia. Sidoarjo: Indomedia Pustaka.

Bohari, Ansar, Muh Tamrin, 2019. Pengaruh Kompensasi, Sarana Prasarana Melalui Kepuasan Kerja Terhadap Kinerja Petugas Kebersihan pada Dianas Lingkungan Hidup dan Kehutan Kabupaten Bulukumba, Junal of Management Yume Vol,2 No.2 (2019)

Bryan Filliantoni, dkk (2019) Pengaruh Disiplin Kerja dan Stres Kerja Terhadap Kinerja Karyawan Melalui Mediasi Kepuasan Kerja pada Karyawan Indomobil Nissan-Datsun Solobaru. Edunomika Vol. 03, No. 01 (Pebruari 2019)

Didi Hartono (2014) Pengaruh Sarana Prasaran dan Lingkungan Kerja Terhadap Kinerja Pegawai Pada Dinas Pendidikan Kota Banjarbaru. Kindai, vol. 1 nomor 2. April-Juni (2014)

Ghozali, Imam. 2018. AplikasiAnalisis Multivariate dengan Program IBM SPSS 25. Semarang Badan Penerbit Universitas Diponegoro

Handoko, T. Hani. 2014. Manajemen Personalia dan Sumber Daya Manusia. Yogyakarta. BPFE.

Hasibuan, Malayu S.P. 2019. Manajemen Sumber Daya Manusia. Jakarta, Bumi Aksara 
Husein Umar. 2013. Metode Penelitian untuk Skripsi dan Tesis. Jakarta: Rajawali

James I Gibson, 2018, Organisasi: Perilaku, Struktur, Proses. Jakarta, Erlangga

Jannah, Annita dkk. 2014. Pengaruh Kompensasi, Pengembangan Karir, dan Disiplin Kerja Terhadap Kinerja Pegawai Dinas Pendapatan Daerah Kota Cimahi.Jurnal Ekonomi, Bisnis \& Enterpreneurship Vol. 8, No. 2, Maret 2014. ISSN 2443-0633

Maharjan, Sarita. 2012. Association Between Work Motivation and Job Satisfaction of Collage Teachers. Administrative and Management Review. Vol. 24, No. 2. pp. 45-55.

Maharjan. (2012). Assosiation between Work Motivation and Job Satisfaction of College Teachers Administrative and Management Review Vol. 24, No 2.

Murti, Harry dan Veronika Agustini Srimulyani. 2013. Pengaruh Motivasi Terhadap Kinerja Pegawai Dengan Variabel Pemediasi Kepuasaan Kerja Pada PDAM Kota Madiun. Jurnal Riset Manajemen dan Akuntansi. Volume 1. Nomor 1.

Nurinaya, 2017 Pengaruh Komunikasi, Motivasi, Sarana Prasarana dan Deskripsi Pekerjaan Terhadap Kinerja Karyawan Universitas Muhammadiyah Makassar. Jurnal Economix Volume 5 Nomor 2 Desember 2017

Parwanto dan Wahyuddin. 2011. Pengaruh FaktorFaktor Kepuasan Kerja terhadap Kinerja Karyawan Pusat Pendidikan Komputer Akuntansi Imka Dl Surakarta.Jurnal. (Online) (diakses 7 Februari 2018).

Rizal, Muhamad., M Syafiie Idrus., and Djumahir, Rahayu Mintarti. 2015. Effect of Compensation on Motivation, Organizational Commitment and Employee Performance (Studiesat Local Revenue Management in Kendari City). International Journal of Business and Management Invention, 3(2):64-79.

Rustam (2018) Pengaruh Manajemen Sarana dan Prasarana terhadap Kepuasan Kerja Guru di MAN 1 Majene. Undergraduate thesis, Universitas Islam Negeri Alauddin Makassar.

Siti Fatimah, (2017) Pengaruh Motivasi, Disiplin dan Lingkungan Kerja Fisik Terhadap Kinerja Pegawai Dengan Kepuasan Pegawai Sebagai Variabel Intervening (Studi Kasus Pada Dinas Kebudayaan dan Pariwisata Kota Semarang) Semarang Jurnal Universitas Negeri.

Sugiyono. 2016. Metode Penelitian Kuantitatif Kualitatif dan R\&D. Bandung, Alfabeta.

Shah, et.al. (2012), "Factors Affecting Pakistan's University Students' purchase intention towards foreign apparel brands", Journal of Management vol 17, 2012,1 pp.114

Siti Fatimah, Aminuddin Irfani. 2018. Pengaruh Kompensasi Terhadap Kinerja Karyawan Pada CV. Cihanjuang Inti Teknik. Prodi Manajemen, fakultas Ekonomi Dan Bisnis, Universitas Islam Bandung. Vol 4. No. 1
Sondang P, Siagian. 2018. ManajemenSumber Daya Manusia. Jakarta: Bumi Aksara

Sukirman. Hubungan Kepuasan Kerja Dengan Disiplin Kerja Karyawan Bagian Produksi PT. BINTRATEX Semarang, ISSN : $1979-6889$

Syafaruddin (2013) Pengaruh Motivasi, Kepemimpinan, Disiplin Kerja, dan Sarana Prasarana Terhadap Kinerja Pegawai BAPPDA Kabupaten Manokwari Provinsi Papua Barat. Home $>$ Vol.2 No.1 (2013) Competitivenes. Jurnal Universitas Muhammadiyah Makassar. P-ISSN : 1978-3035.

Tjutju Yuniarsih dan Suwatno. 2016. Manajemen Sumber Daya Manusia. Bandung: Alfabeta.

Wibowo, 2016. Manajemen Kinerja, Edisi Kelima, Jakarta PT.Rajagrafindo Persada 